\title{
Article \\ Effect of Plant Spacings on Growth, Physiology, Yield and Fiber Quality Attributes of Cotton Genotypes under Nitrogen Fertilization
}

\author{
Ishrat Zaman ${ }^{1}$, Muqarrab Ali ${ }^{1, *}$, Khurram Shahzad ${ }^{2}$, Muhammad Saeed Tahir ${ }^{3}$, Amar Matloob ${ }^{1}$, Wazir Ahmad ${ }^{4}$, \\ Saud Alamri ${ }^{5}{ }^{10}$, Muhammad Rizwan Khurshid ${ }^{6}$, Muhammad Mubashir Qureshi ${ }^{7}$, Allah Wasaya ${ }^{8}$ (D), \\ Khurram Shehzad Baig ${ }^{9}$, Manzer H. Siddiqui ${ }^{5}$, Shah Fahad ${ }^{10,11,+}$ (D) and Rahul Datta ${ }^{12,+(D)}$
}

\section{check for} updates

Citation: Zaman, I.; Ali, M.; Shahzad, K.; Tahir, M.S.; Matloob, A.; Ahmad,

W.; Alamri, S.; Khurshid, M.R.; Qureshi, M.M.; Wasaya, A.; et al. Effect of Plant Spacings on Growth, Physiology, Yield and Fiber Quality Attributes of Cotton Genotypes under Nitrogen Fertilization. Agronomy 2021, 11, 2589. https://doi.org/ 10.3390/agronomy11122589

Academic Editor: Jane K. Dever

Received: 16 October 2021

Accepted: 15 December 2021

Published: 19 December 2021

Publisher's Note: MDPI stays neutral with regard to jurisdictional claims in published maps and institutional affiliations.

Copyright: (c) 2021 by the authors. Licensee MDPI, Basel, Switzerland. This article is an open access article distributed under the terms and conditions of the Creative Commons Attribution (CC BY) license (https:/ / creativecommons.org/licenses/by/ $4.0 /$ )
1 Department of Agronomy, Muhammad Nawaz Sharif University of Agriculture, Multan 60000, Pakistan; ishratzaman01@gmail.com (I.Z.); amar.matloob@mnsuam.edu.pk (A.M.)

2 Department of Soil Science, Lasbela University of Agriculture, Water and Marine Sciences, Uthal 89250, Pakistan; khurram.shahzad@luawms.edu.pk

3 Department of Agronomy, Faculty of Agricultural Sciences and Technology, Bahauddin Zakariya University, Multan 60800, Pakistan; saeedtahir57@yahoo.com

4 Department of Soil Science, Muhammad Nawaz Sharif University of Agriculture, Multan 60000, Pakistan; wazir.ahmed@mnsuam.edu.pk

5 Department of Botany and Microbiology, College of Science, King Saud University, Riyadh 11451, Saudi Arabia; saualamri@ksu.edu.sa (S.A.); mhsiddiqui@ksu.edu.sa (M.H.S.)

6 Oilseeds Research Institute, Ayub Agriculture Research Institute, Faisalabad 38850, Pakistan; rizwanaari@gmail.com

7 Plant Nutrition Section, Mango Research Institute, Multan 60000, Pakistan; mubashir116@yahoo.com

8 College of Agriculture, Bahadur Sub-Campus Layyah, Bahauddin Zakariya University, Layyah 31200, Pakistan; Wasayauaf@gmail.com

9 Soil \& Water Testing Laboratory, Muzaffargarh 34200, Pakistan; ksb2004@gmail.com

10 Hainan Key Laboratory for Sustainable Utilization of Tropical Bioresource, College of Tropical Crops, Hainan University, Haikou 570228, China; shah_fahad80@yahoo.com

11 Department of Agronomy, The University of Haripur, Khyber Pakhtunkhwa 22620, Pakistan;

12 Department of Geology and Pedology, Faculty of Forestry and Wood Technology, Mendel University in Brno, Zemedelska1, 61300 Brno, Czech Republic; rahulmedcure@gmail.com

* Correspondence: muqarrab.ali@mnsuam.edu.pk

+ Equal in contribution of correspondence.

Abstract: Cotton is a major cash crop of Pakistan that provides high foreign exchange and plays an important role in agriculture, industry, and economic development. The plant population is important in achieving high cotton yield and fiber quality attributes in irrigated conditions. Most farmers maintain plant spacing according to their local tradition, and often ignore the varietal characteristics in Pakistan that cause low yield and poor quality of products. Therefore, standardization of plant spacings according to varietal characteristics is important to achieve higher yield and fiber quality. A field experiment was carried out at the Agronomic Research Area, Muhammad Nawaz Shareef University of Agriculture, Multan, Pakistan in 2017, in order to evaluate the performance of four cotton cultivars (MNH-1016, FH-Lalazar, NIAB-878, and Cyto-124) under five plant spacings (15.0, $22.5,30.0,37.5$, and $45.0 \mathrm{~cm}$ ), comparing them with and without nitrogen application. Nitrogen fertilization was applied at the rate of $197 \mathrm{~kg} \mathrm{ha}^{-1}$. The experiment was replicated thrice, as per Randomized Complete Block Design with factorial arrangements. The results showed that nitrogen application of $197 \mathrm{~kg} \mathrm{ha}^{-1}$ showed a positive impact on all crop parameters compared to plots where no nitrogen fertilizer was applied. The wider plant spacing $(45 \mathrm{~cm})$ increased the values of many cotton parameters compared with other plant spacings $(22.5,30.0,37.5$ and $45.0 \mathrm{~cm})$, but the seed cotton yield was found to be higher in the narrow plant spacing $(15 \mathrm{~cm})$. However, fiber quality parameters such as GOT, staple strength, and micronaire showed higher values under wider plant spacing $(45.0 \mathrm{~cm})$. The varieties showed a mixed effect on cotton productivity and fiber quality. The MNH-1016 significantly impacted yield-contributing parameters such as bolls plant $^{-1}$, boll weight and seed cotton yield. The NIAB-878 showed a higher photosynthetic rate and stomatal conductance compared to other varieties. Therefore, the wider plant spacing with nitrogen 
application could be a better strategy to increase cotton growth, yield, physiology, and fiber quality. However, long-term studies under different climatic conditions are suggested for wider plant spacing with nitrogen fertilizers.

Keywords: agronomic practice; cotton; macronutrient; quality attributes; yield

\section{Introduction}

Cotton (Gossypium hirustum L.) is an essential cash crop of Pakistan that provides yarn and edible oil. Pakistan earns 55\% of its total foreign exchange earnings by exporting lint and value-added cotton products. In addition, cotton supplies raw materials for its textile and oil manufacturing industries, and cotton contributes $0.8 \%$ of the GDP and $4.1 \%$ of the agriculture value addition of the country [1]. In 2019-2020, cotton was cultivated on 2527 hectares with a total production of 9.17 million bales. The cotton crop registered a decline of $6.9 \%$ to 9.86 million bales [2].

It is important to plan improved management practices that enhance cotton yield potential. Cotton is extremely susceptible to abiotic stresses. Cotton growth and development are significantly influenced by climatic adversaries and seasonal management practices such as variety selection, sowing date, sowing method, plant spacing, water requirement, seed treatment, and appropriate fertilizer application [3,4].

Planting density is very critical for achieving maximum crop development and yield potential under irrigated conditions. In cotton, planting density has a significant effect on the development and yield attributes of the cotton plant. Nevertheless, the optimum plant population per unit area varies as a function of variety. According to its plant architecture, each variety has its plant-to-plant distance requirements [5]. Farmers used their conventional planting methods to sustain plant spacing rather than varietal requirements, and thus, did not attain high crop yield. The plant population affects crop growth dynamics by imposing competition among plants for space, solar radiation, nutrients, and moisture uptake.

Arshad et al. [6] revealed that the planting-density factor plays a crucial role in seed cotton yield. Humidity increases due to higher planting density, providing favourable conditions for insect attack in cotton crops and increasing the attack of cotton leaf curl virus and rotting of bolls [7]. At lower planting density, sympodial branches are longer, and a high percentage of bolls are produced on outer fruiting branches. On the other hand, primary-position bolls produced by narrow plant density are higher in boll weight and higher yield [8] Maximum yield can be obtained by maintaining the optimum plant population according to plant morphological characteristics. When the cotton crop's plant population is low, the yield and fiber quality are also affected [9]).

In contrast, deficiency of primary nutrients, especially nitrogen, plays a significant role in the growth and development of cotton. Nitrogen is commonly considered the most limiting factor for cotton growth, yield, and radiation use efficiency [10]. Nitrogen application in cotton crops enhances leaf area index and flowering when applied before flowering [11]. On the other hand, high nitrogen availability may shift the balance between vegetative and reproductive growth toward excessive vegetative development, thus delaying crop maturity and reducing seed cotton yield [12]. Higher doses of nitrogen application lead toward more vegetative growth and result in crop maturity delay and ultimately a reduction in crop yield [12].

In addition, nitrogen is the fundamental part of several biochemical compounds. Its unavailability influences photosynthetic rate, crop growth rate and source-sink association of crops [11]. It also prevents the plant from boll (fruit) and square abscission [13,14]. Moreover, cotton genotype and nitrogen relation effect found that Bt cotton exhibited a quadratic nitrogen response, whereas non-Bt cotton has a linear nitrogen response [15]. Ali et al. [16] found that the recommended dose of nitrogen $\left(150 \mathrm{~kg} \mathrm{ha}^{-1}\right)$ produced taller 
plants with high boll number and weight. The hypothesis was made that wider plant spacing with nitrogen application could improve the productivity of cotton cultivars.

Therefore, the present study was conducted with the main objective of determining the optimum plant spacing in different cotton cultivars without nitrogen and with the recommended dose of nitrogen on the impact of cotton growth, physiology, yield, and fiber quality parameters.

\section{Materials and Methods}

\subsection{Experimental Site}

The field trial was carried out at the Agronomic Research Area, MNS University of Agriculture, Multan, Pakistan ( $\left.30.2^{\circ} \mathrm{N}, 71.45^{\circ} \mathrm{E}\right)$, during the cotton growing season in 2017 (Figure 1). Soil properties were measured as they vary with land use $[15,16]$. The soil texture was sandy clay loam ( $34 \%$ sand, $36 \%$ silt and clay $30 \%$ ) with ECe $9.56 \mathrm{dSm}^{-1}, \mathrm{pH} 8.0$, organic matter content $0.72 \%$, total nitrogen $0.036 \%$, available phosphorous $9.20 \mathrm{mg} \mathrm{kg}^{-1}$, and available potassium $250 \mathrm{mg} \mathrm{kg}^{-1}$. All the data were obtained by pre-sowing soil sampling.
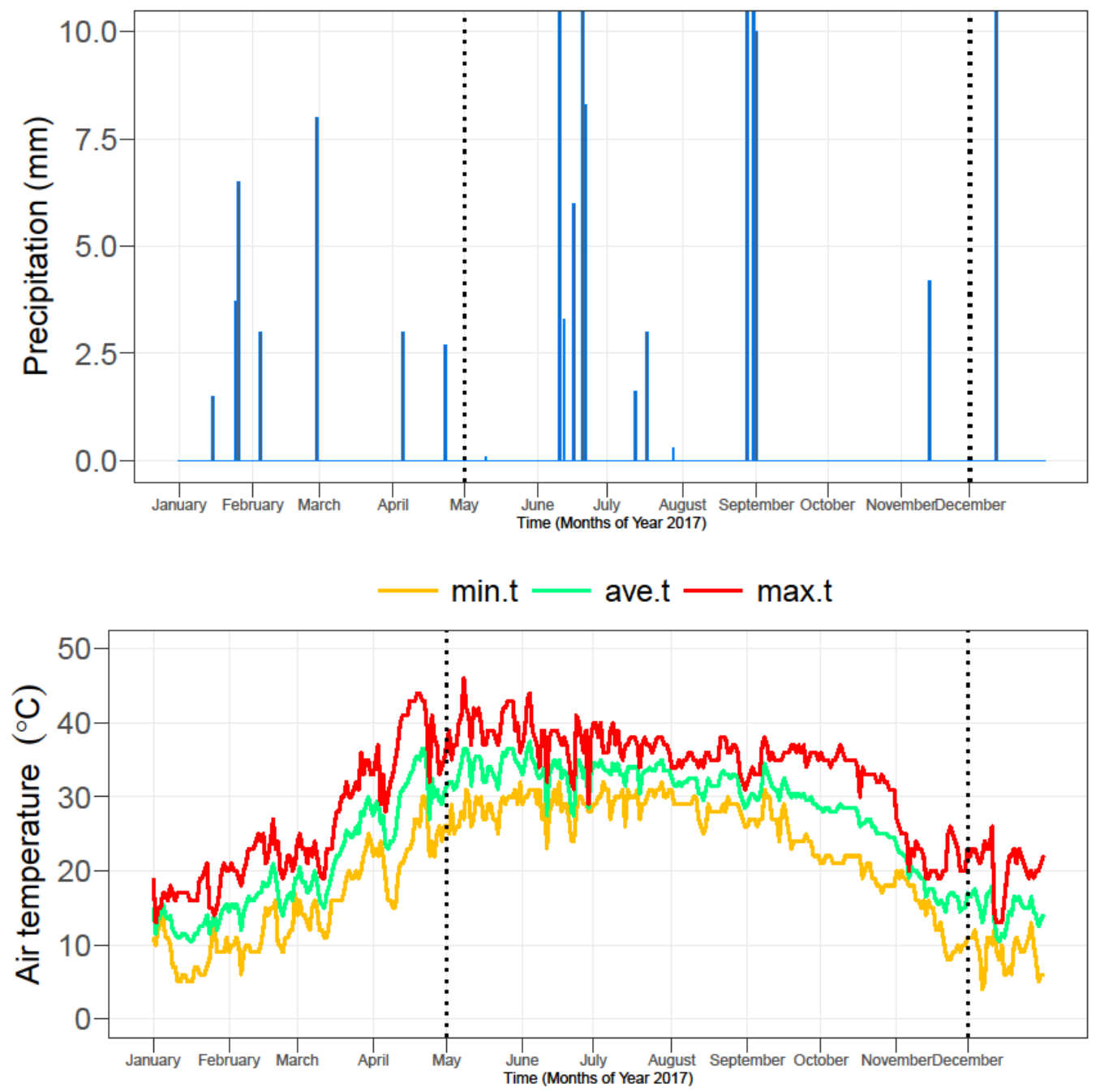

Figure 1. The average minimum, maximum and mean air temperature and rainfall in Multan, Pakistan during 2017. The dotted lines show the duration of experiment.

\subsection{Treatments}

Treatments consisted of a factorial combination of four genotypes (variety $\mathrm{MNH}-$ 1016, experimental line FH-Lalazar, variety NIAB-878, experimental line Cyto-124), five 
plant spacings $(15.0 \mathrm{~cm}, 22.5 \mathrm{~cm}, 30.0 \mathrm{~cm}, 37.5 \mathrm{~cm}, 45.0 \mathrm{~cm})$ and nitrogen fertilization $\left[\mathrm{N}_{0}\right.$ $\left.\left(0 \mathrm{~kg} \mathrm{~N} \mathrm{ha}^{-1}\right), \mathrm{N}_{1}\left(197 \mathrm{~kg} \mathrm{~N}^{-1}\right)\right]$. Treatments were carried out in a randomized complete block design (RCBD) under factorial arrangements with three replicates. The net plot size was $9 \mathrm{~m} \times 1.5 \mathrm{~m}$. The number of rows were two within the treatment plots.

\subsection{Field Experiment}

The seedbeds were prepared by cultivating the soil three times with a tractor-mounted plough followed by planking. Application of phosphatic and potassium fertilizer were applied at the time of land preparation by broadcasting to the entire field, i.e., Triple superphosphate (TSP) at the amount of $86 \mathrm{~kg} \mathrm{ha}^{-1}$ and Sulphate of Potash (SOP) at the rate of $80 \mathrm{~kg} \mathrm{ha}^{-1}$. Nitrogen was applied $197 \mathrm{~kg} \mathrm{ha}^{-1}$. Three splits fulfilled the nitrogen requirement. The first dose of nitrogen was applied at 30 days after sowing (DAS), the second dose at $60 \mathrm{DAS}$, and the third dose of nitrogen was applied at 90 DAS. When soil attained optimum moisture level, the seedbed was prepared $(75 \mathrm{~cm})$ and sowing was performed. The seeds were sown on beds manually by the dibbling method according to plant spacing treatments. The row spacing was maintained at $75 \mathrm{~cm}$. All the recommended agronomic practices were carried out as per the local agriculture department. Within $24 \mathrm{~h}$ of sowing, pendimethalin (pre-emergence herbicide, $1000 \mathrm{~mL}$ per acre) was sprayed using a flat fan nozzle. The furrows were again irrigated three days after dibbling to achieve successful seed emergence. In total, nine irrigations were applied when needed at various plant developmental stages until the crop reached physiological maturity. Plant protection measures were adopted against sucking pests and bollworms when needed.

\subsection{Data Collection}

Plant height, number of nodes plant ${ }^{-1}$, monopodial and sympodial branches were measured from five selected plants from each plot. The seeds' cotton was picked from the whole plot manually and then the yield was converted into $\mathrm{kg} \mathrm{ha}^{-1}$. The bolls were air-dried to obtain moisture contents below $11 \%$, and the weight of individual bolls was measured to obtain the average boll weight. A representative tester of $100 \mathrm{~g}$ from all treatment plots was used for ginning. The lint obtained from each sample was weighed and it's GOT was calculated by using the following formula [17]:

$$
\text { Ginning out turn }(\mathrm{GOT})=\frac{\text { Weight of lint }(\mathrm{g})}{\text { Weight of seed cotton }(\mathrm{g})} \times 100
$$

The fiber length, strength, and fineness were measured by placing a $2.0 \mathrm{~g}$ sample of lint in a high-value instrument (HVI), available in the Fiber Technology Section, Central Cotton Research Institute, Multan, Pakistan.

The leaf area was measured by a portable leaf-area meter (Model CI-202, CID lBio Science, Inc. 1554 NE 3rd Ave Camas, WA98607). The average leaf area index (LAI) was calculated by using the formula as follows [18]:

$$
\text { Leaf Area Index }(\text { LAI })=\frac{\text { Leaf area perplant }}{\text { Ground area per plant }}
$$

Stomatal conductance and net photosynthetic rate were measured with the help of a portable infrared gas analyzer system (IRGA) CID, Inc. Photosynthetic systems CI-340. Chlorophyll contents were measured by a portable chlorophyll meter (Minolta SPAD502). Chlorophyll readings of 10 plants per plot were taken from the fourth and fifth uppermost, fully expanded leaves on the main stem of cotton. The plants were sampled weekly for seven weeks, beginning one week after the onset of "pinhead". Afterwards, the 10 measured leaves were detached for the determination of total nitrogen content.

Total nitrogen content was analyzed by the Kjeldhal's digestion and distillation method [19]. Total nitrogen in the plant samples was determined by digesting the plant sample with sulphuric acid and digestion mixture. For this purpose, $0.25 \mathrm{~g}$ plant material 
was weighed in a digestion tube, then a $4.0 \mathrm{~g}$ digestion mixture $\left(\mathrm{K}_{2} \mathrm{SO}_{4}\right.$ and $\mathrm{CuSO}_{4} \cdot 5 \mathrm{H}_{2} \mathrm{O}$ in 9:1 ratio) and $20 \mathrm{~mL}$ of sulphuric acid were added. The samples were kept overnight. The samples were digested on the digestion rack at $350{ }^{\circ} \mathrm{C}$ temperature till the blackish material turned green. The digestion tube was removed from the digestion rack and made to a volume $100 \mathrm{~mL}$ of the digest. Total nitrogen in the plant samples was determined with UDK automatic nitrogen distillation apparatus, available in the Plant Nutrition Laboratory of Soil Salinity Research Institute (SSRI), Pindi Bhattian, Pakistan, using 40\% NaOH solution and $4 \%$ boric acid. The sample was back-titrated with $0.1 \mathrm{~N} \mathrm{H}_{2} \mathrm{SO}_{4}$ to the reddish endpoint [20].

Total phosphorus and potassium in plant samples were determined by performing wet digestion of plant samples with nitric acid and perchloric acid. For this purpose, $0.50 \mathrm{~g}$ material was weighed in a $250 \mathrm{~mL}$ conical flask, then $10 \mathrm{~mL}$ nitric acid and $5 \mathrm{~mL}$ perchloric acid were added. The samples were kept overnight. The samples were digested until 2-3 mL milky solution was left in the conical flask. The digested samples were removed and the final volume of solution was made to $50 \mathrm{~mL}$.

The digested aliquot with nitric acid and perchloric acid was used to determine total P from plant samples. For this purpose, $5 \mathrm{~mL}$ aliquot was taken in a $50 \mathrm{~mL}$ volumetric flask, then we added $5 \mathrm{~mL} 0.25 \%$ ammonium metavanadate solution and $5 \mathrm{~mL} \mathrm{5 \%}$ ammonium molybdate solution. The final volume was made to $50 \mathrm{~mL}$. A yellow color was formed. Samples were kept for $30 \mathrm{~min}$, a standard was prepared, and color intensity was measured at $400 \mathrm{~nm}$ wavelength with a PD-303S Apel spectrophotometer in the plant nutrition laboratory at SSRI, Pindi Bhattian [21].

The digested aliquot with nitric acid and perchloric acid was used to determine total $\mathrm{K}$ from plant samples. For this purpose, $5 \mathrm{~mL}$ aliquot was taken in a $50 \mathrm{~mL}$ volumetric flask, then, a final volume was made to $50 \mathrm{~mL}$ with distilled water. Standard solution readings were noted on Jen way PFP-7 flame photometer in the plant nutrition laboratory at SSRI, PindiBhattian [21].

\subsection{Statistical Analysis}

The collected data were analyzed using $\mathrm{R}$ software (Version 4.1.2) by applying a linear model. The "nmle" package was used to fit the linear model in R. Each factor was statistically analyzed separately as this was an RCBD factorial experiment. The mean separation was performed at $p<0.05$ with Tukey multiple comparison test using "emmeans" package in $R$.

\section{Results}

\subsection{Plant Height, Monopodial Branches, Sympodial Branches, Leaf Area and Nodes Plant ${ }^{-1}$}

The main effects of variety of nitrogen rate and variety $\times$ plant spacing were found to be significant for plant height at $p<0.05$ (Table 1). The nitrogen application of $197 \mathrm{~kg} \mathrm{ha}^{-1}$ showed a $22.1 \%$ increase in plant height when compared to no nitrogen application. The $15.0 \mathrm{~cm}$ plant spacing showed a $2.8 \%, 5.6 \%, 4.2 \%$ and $4.9 \%$ increase in plant height compared to other plant spacings 22.5,30.0, 37.5, and $45.0 \mathrm{~cm}$, respectively. The MNH-1016 showed 10.6\&, 13.9\&, 9.1\& and 9.9\% higher plants than FH-Lalazar, NIAB-878 and Cyto124, respectively (Table 2 ).

The main significant effects of plant spacing and nitrogen rate were on the monopodial branches (Table 1). The nitrogen application $197 \mathrm{~kg} \mathrm{ha}^{-1}$ increased by $25.0 \%$ the monopodial branches compared to with no nitrogen application. The wider plant spacing performs better than the narrow plant spacing. The $45.0 \mathrm{~cm}$ plant spacing showed a $22.1 \%, 32.6 \%$, $16.3 \%$ and $7.5 \%$ increase in monopodial branches compared to 15.0, 22.5, 30.0, 37.5, and $45.0 \mathrm{~cm}$ plant spacings, respectively (Table 2). The cultivar Cyto-124 showed the highest number of monopodial branches of all cultivars (MNH-1016, FH-Lalazar, NIAB-878, and Cyto-124).

Table 1. P value of main and interaction effect of variety, plant spacing and nitrogen rates on the cotton growth, physiology, yield, and fiber quality attributes.

\begin{tabular}{|c|c|c|c|c|c|c|c|c|c|}
\hline Effect & $\begin{array}{l}\text { Plant } \\
\text { Height }\end{array}$ & $\begin{array}{c}\text { Monopodial } \\
\text { Branches }\end{array}$ & $\begin{array}{c}\text { Sympodial } \\
\text { Branches }\end{array}$ & Leaf Area & $\begin{array}{l}\text { Nodes } \\
\text { Plant }^{-1}\end{array}$ & $\begin{array}{c}\text { Bolls } \\
\text { Plant }^{-1}\end{array}$ & $\begin{array}{c}\text { Boll } \\
\text { Weight }\end{array}$ & $\begin{array}{l}\text { Seed } \\
\text { Cotton } \\
\text { Yield }\end{array}$ & GOT \\
\hline Variety (V) & $<0.001$ & 0.320 & $<0.001$ & $<0.001$ & $<0.001$ & $<0.001$ & $<0.001$ & $<0.001$ & $<0.001$ \\
\hline
\end{tabular}


Table 2. The effect of nitrogen rates, plant spacing and variety on the cotton plant height, monopodial branches, sympodial branches, leaf area and nodes plant ${ }^{-1}$.

\begin{tabular}{|c|c|c|c|c|c|}
\hline Factors & $\begin{array}{l}\text { Plant Height } \\
\text { (cm) }\end{array}$ & $\begin{array}{c}\text { Monopodial } \\
\text { Branches }\end{array}$ & $\begin{array}{c}\text { Sympodial } \\
\text { Branches }\end{array}$ & $\begin{array}{l}\text { Leaf Area } \\
\left(\mathrm{cm}^{2}\right)\end{array}$ & Nodes Plant $^{-1}$ \\
\hline \multicolumn{6}{|c|}{ Nitrogen Rate Effect } \\
\hline $\mathrm{N}_{0}\left(0 \mathrm{~kg} \mathrm{Nha}^{-1}\right)$ & $130.57 \pm 11.21 \mathrm{~b}$ & $1.28 \pm 0.28 b$ & $19.46 \pm 2.83 a$ & $228.75 \pm 24.95 b$ & $26.63 \pm 4.36 b$ \\
\hline $\mathrm{N}_{1}\left(197 \mathrm{~kg} \mathrm{~N} \mathrm{ha}^{-1}\right)$ & $158.73 \pm 15.42 \mathrm{a}$ & $1.60 \pm 0.35 a$ & $16.61 \pm 3.38 b$ & $266.08 \pm 33.30 \mathrm{a}$ & $29.60 \pm 4.67 \mathrm{a}$ \\
\hline \multicolumn{6}{|c|}{ Plant $\times$ Plant Spacing } \\
\hline $15.0 \mathrm{~cm}$ & $149.26 \pm 27.56 a$ & $1.14 \pm 0.25 \mathrm{~d}$ & $19.7 \pm 3.169 \mathrm{a}$ & $279.58 \pm 32.99 c$ & $23.25 \pm 3.70 \mathrm{~d}$ \\
\hline $22.5 \mathrm{~cm}$ & $145.61 \pm 16.70 \mathrm{a}$ & $1.29 \pm 0.30 \mathrm{~d}$ & $19.04 \pm 2.62 \mathrm{ab}$ & $268.75 \pm 27.39 b c$ & $25.62 \pm 3.80 c$ \\
\hline $30.0 \mathrm{~cm}$ & $141.98 \pm 18.04 a$ & $1.47 \pm 0.26 b c$ & $17.83 \pm 2.95 b$ & $244.04 \pm 26.51 b$ & $29.00 \pm 3.65 b$ \\
\hline $37.5 \mathrm{~cm}$ & $143.72 \pm 17.04 a$ & $1.59 \pm 0.32 \mathrm{ab}$ & $17.54 \pm 3.24 \mathrm{bc}$ & $230.42 \pm 20.59 c$ & $30.62 \pm 3.49 \mathrm{ab}$ \\
\hline $45.0 \mathrm{~cm}$ & $142.68 \pm 16.62 \mathrm{a}$ & $1.71 \pm 0.31 \mathrm{a}$ & $16.00 \pm 3.93 c$ & $214.29 \pm 16.81 d$ & $32.08 \pm 4.76 \mathrm{a}$ \\
\hline \multicolumn{6}{|c|}{ Varietal Effect } \\
\hline MNH-1016 & $156.16 \pm 23.53 a$ & $1.39 \pm 0.32 \mathrm{a}$ & $20.23 \pm 2.59 a$ & $236 \pm 39.37 c$ & $29.16 \pm 4.55 a$ \\
\hline FH-Lalazar & $141.84 \pm 14.77 \mathrm{~b}$ & $1.42 \pm 0.33 a$ & $19.80 \pm 2.72 \mathrm{a}$ & $245 \pm 30.02 b c$ & $27 \pm 4.80 \mathrm{~b}$ \\
\hline NIAB-878 & $137.60 \pm 17.34 b$ & $1.43 \pm 0.37 a$ & $16.33 \pm 3.05 b$ & $250 \pm 67.84 a b$ & $29.90 \pm 4.04 a$ \\
\hline Cyto-124 & $143.01 \pm 16.97 \mathrm{~b}$ & $1.52 \pm 0.38 \mathrm{a}$ & $15.80 \pm 2.85 b$ & $257 \pm 29.25 a$ & $26.40 \pm 4.83 b$ \\
\hline
\end{tabular}

Different letters are showing significant difference at $p \leq 0.05$.

The main significant effect of variety, plant spacing, and nitrogen rate was found on the sympodial branches per plant (Table 1). The nitrogen application of $197 \mathrm{~kg} \mathrm{ha}^{-1}$ reduced the number of sympodial branches compared to with no nitrogen application. The narrow plant spacing was found to be better for the number of sympodial branches per plant than wider plant spacing. The MNH-1016 variety showed higher sympodial branches per plant over other FH-Lalazar, NIAB-878, and Cyto-124 cultivars (Table 2).

The main significant interaction effect of variety, nitrogen rate, and plant spacing was found to be on cotton leaf area (Table 1). The nitrogen application $197 \mathrm{~kg} \mathrm{ha}^{-1}$ increased by $16.7 \%$ the leaf area compared to the plot where no nitrogen was applied. The plant spacing $15.0 \mathrm{~cm}$ increased the leaf area by $4.1 \%, 14.3 \%, 21.3 \%$, and $30.4 \%$ compared to plant spacings 22.5, 30.0, 37.5 and $45.0 \mathrm{~cm}$, respectively. The MNH-1016 showed an increase of $2.2 \%, 23.9 \%$ and $28.0 \%$ over FH-Lalazar, NIAB-878, and Cyto-124, respectively (Table 2).

The main significant effects of variety, plant spacing and nitrogen rate were found on cotton nodes per plant (Table 1). The nitrogen application of $197 \mathrm{~kg} \mathrm{ha}^{-1}$ increased the number of nodes per plant compared to no nitrogen application (Table 2). The wider plant spacing showed a higher number of nodes compared to narrow plant spacings. The NIAB-878 variety showed a higher number of nodes per plant than MNH-1016, FH-Lalazar and Cyto-124 (Table 2).

\subsection{Bolls per Plant, Boll Weight and Seed Cotton Yield}

The main effect of variety, plant spacings, and nitrogen rate was found significantly on the bolls per plant. The interaction effect of variety $\times$ nitrogen rate and plant spacing $\times$ nitrogen rate was also found to be significant (Table 1). The nitrogen application $197 \mathrm{~kg} \mathrm{ha}^{-1}$ showed two times higher bolls per plant than the no nitrogen application. The plant spacing $45.0 \mathrm{~cm}$ increased by $71.5 \%, 56.3 \%, 33.4 \%$, and $20.7 \%$ the number of bolls per plant compared to the $15.0,22.5,30.0,37.5$ and $45.0 \mathrm{~cm}$ plant spacings, respectively. The MNH-1016 increased by $17.3 \%, 0.7 \%$ and $43.5 \%$ the number of bolls per plant compared to FH-Lalazar, NIAB-878, and Cyto-124, respectively (Figure 2).

The main significant effect of variety, plant spacing, and nitrogen rates was found on the boll weight (Table 1). The nitrogen application increased the boll weight compared to the no nitrogen application. The increase in plant spacings increased the boll's weight. The 
MNH-1016 showed the highest bolls weight, while cyto-124 showed minimum boll weight (Figure 2).

The main significant effect of variety, plant spacing, and nitrogen rate was found on the seed cotton yield at $p<0.05$. The interaction effect of variety $\times$ plant spacing was also found to be significant (Table 1). The increase in seed cotton yield was $33.1 \%$ with nitrogen application $197 \mathrm{~kg} \mathrm{ha}^{-1}$ compared to the no-nitrogen application. The seed cotton yield reduced with increasing the plant spacing. The higher seed cotton yield was at $15.0 \mathrm{~cm}$, while the lowest seed cotton yield was at $45.0 \mathrm{~cm}$. The $15 \mathrm{~cm}$ plant spacing showed an increase of $7.1 \%, 21.3 \%, 39.3 \%$, and $64.3 \%$ in seed cotton yield compared to $22.5,30.0,37.5$, and $45.0 \mathrm{~cm}$ plant spacings, respectively. The variety MNH-1016 showed higher seed cotton among other cultivars (Figure 2).

\subsection{Ginning out Turn Staple Length and Fiber Fineness}

The main effect of variety and nitrogen rates were found to be significant on the ginning out turn (GOT) at $p<0.05$ (Table 1). The nitrogen application $197 \mathrm{~kg} \mathrm{ha}^{-1}$ increased GOT 3.4\% over no-nitrogen application. The plant spacing 45.0 showed the highest GOT while plant spacing $30.0 \mathrm{~cm}$ showed the lowest GOT. The variety FH-Lalazar showed an increase of $2.3 \%, 7.9 \%$, and $45.8 \%$ increase in GOT compared to MNH-1016, NIAB-878, and Cyto-124, respectively (Table 3 ).
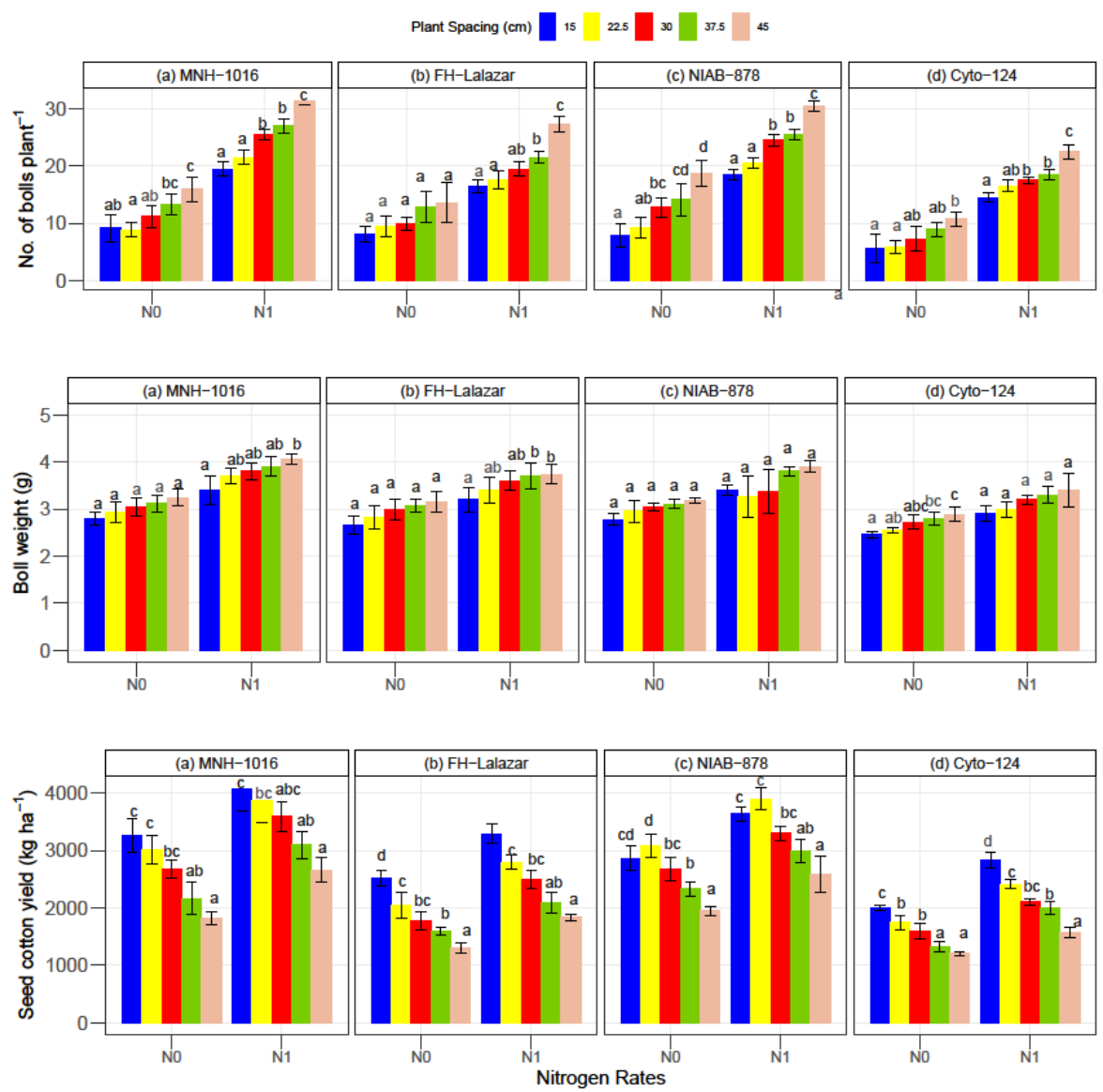

Figure 2. Impact of spacing on the seed cotton yield, boll weight, and no. of bolls plant ${ }^{-1}$ of four cotton cultivars under different nitrogen applications; No (no nitrogen application) and N1 (nitrogen application $197 \mathrm{~kg} \mathrm{ha}^{-1}$ ). The same letter (s) within variety and nitrogen rate are statistically nonsignificant. Error bar represents the standard deviation $(\mathrm{n}=3)$. Different letters are showing significant difference at $p \leq 0.05$. 
Table 3. The effect of nitrogen rates, plant spacing and variety on the cotton ginning out turn (GOT), staple, and micronaire.

\begin{tabular}{cccc}
\hline Factors & Got & Staple & Micoonaire \\
\hline \multicolumn{4}{c}{ Nitrogen Rates Effect } \\
\hline $\mathrm{N}_{0}\left(0 \mathrm{~kg} \mathrm{~N} \mathrm{ha}^{-1}\right)$ & $31.30 \pm 5.25 \mathrm{a}$ & $21.64 \pm 2.85 \mathrm{~b}$ & $3.59 \pm 0.53 \mathrm{~b}$ \\
$\mathrm{~N}_{1}\left(197 \mathrm{~kg} \mathrm{~N} \mathrm{ha}^{-1}\right)$ & $32.34 \pm 5.10 \mathrm{~b}$ & $24.55 \pm 3.88 \mathrm{a}$ & $4.59 \pm 0.41 \mathrm{a}$ \\
\hline \multicolumn{4}{c}{ Plant $\times$ Plant Spacing effect } \\
\hline $15.0 \mathrm{~cm}$ & $31.81 \pm 5.21 \mathrm{a}$ & $20.56 \pm 2.66 \mathrm{e}$ & $4.20 \pm 0.56 \mathrm{ab}$ \\
$22.5 \mathrm{~cm}$ & $31.64 \pm 5.47 \mathrm{a}$ & $21.93 \pm 3.00 \mathrm{~d}$ & $4.32 \pm 0.63 \mathrm{ab}$ \\
$30.0 \mathrm{~cm}$ & $31.46 \pm 4.39 \mathrm{a}$ & $23.16 \pm 3.42 \mathrm{c}$ & $4.19 \pm 0.59 \mathrm{ab}$ \\
$37.5 \mathrm{~cm}$ & $31.61 \pm 5.35 \mathrm{a}$ & $24.36 \pm 3.56 \mathrm{~b}$ & $4.07 \pm 0.49 \mathrm{~b}$ \\
$45.0 \mathrm{~cm}$ & $32.58 \pm 5.73 \mathrm{a}$ & $25.47 \pm 3.79 \mathrm{a}$ & $4.40 \pm 0.66 \mathrm{a}$ \\
\hline \multicolumn{4}{c}{ Varietal effect } \\
\hline MNH-1016 & $34.66 \pm 2.67 \mathrm{a}$ & $24.17 \pm 3.46 \mathrm{~b}$ & $4.83 \pm 0.60 \mathrm{a}$ \\
FH-Lalazar & $35.45 \pm 2.52 \mathrm{a}$ & $21.88 \pm 2.99 \mathrm{c}$ & $4.03 \pm 0.44 \mathrm{~b}$ \\
NIAB-878 & $32.862 .65 \mathrm{~b}$ & $25.57 \pm 3.72 \mathrm{a}$ & $4.07 \pm 0.48 \mathrm{~b}$ \\
Cyto-124 & $24.31 \pm 2.87 \mathrm{c}$ & $20.76 \pm 2.54 \mathrm{~d}$ & $4.01 \pm 0.40 \mathrm{~b}$ \\
\hline
\end{tabular}

The values are the mean \pm standard deviation $(n=3)$. The values with the same letter $(\mathrm{s})$ within treatment (nitrogen rate, plant spacing, and variety) are statistically nonsignificant. Different letters are showing significant difference at $p \leq 0.05$.

The main and interaction effects of variety, plant spacings, and nitrogen rate were found to be significant on the staple length (Table 1). The increment in the staple length was 13.4 with the application of nitrogen $197 \mathrm{~kg} \mathrm{ha}^{-1}$ over no-nitrogen application. The staple length increased with increasing the plant spacing. The maximum staple length was found at $45.0 \mathrm{~cm}$, while the minimum staple length was found at $15.0 \mathrm{~cm}$. The variety NIAB-878 showed an increase of 5.8, 16.9, and 23.2\% as compared to FH-Lalazar, MNH-1016 and Cyto-124, respectively (Table 3).

The main effect of variety, plant spacing, and nitrogen rate was significant at $p<0.05$. The interaction effect of variety $\times$ plant spacing and variety $\times$ plant spacing $\times$ nitrogen rate was also found to be significant (Table 1). The higher micronaire was found with the application of nitrogen fertilizer $197 \mathrm{~kg} \mathrm{ha}^{-1}$ over no nitrogen application (Table 3). The plant spacing showed a mixed effect on the micronaire. The maximum micronaire was found at $45.0 \mathrm{~cm}$ plant spacing. However, the micronaire reduction was seen at $37.5 \mathrm{~cm}$ plant spacing. The variety MNH-1016 showed higher micronaire than other varieties. The variety MNH-1016 showed a 19.9\%, 18.7\%, and 20.4\% increase in micronaire over FH-Lalazar, NIAB-878, and Cyto-124, respectively (Table 3).

\subsection{Photosynthetic Rate, Stomatal Conductance and Chlorophyll Content}

The main and interaction effects of variety, plant spacing, and nitrogen rate were found to be significant on the photosynthetic rate at $p<0.05$ (Table 1). The nitrogen application of $197 \mathrm{~kg} \mathrm{ha}^{-1}$ showed a higher photosynthetic rate than the no nitrogen application. The photosynthetic rate increased with an increase in plant spacing. The maximum photosynthetic rate was found where $45.0 \mathrm{~cm}$ plant spacing was practised, while the minimum photosynthetic rate was found with $15.0 \mathrm{~cm}$ plant spacing. The variety NIAB-878 showed an increased photosynthetic rate by $6.3,14.4$, and $24.8 \%$ compared to MNH-1016, FH-Lalazar, and Cyto-124, respectively (Table 4). 
Table 4. The effect of nitrogen rates, plant spacing and variety on photosynthetic rate, stomatal conductance chlorophyll contents.

\begin{tabular}{cccc}
\hline Factors & Photosynthetic Rate & $\begin{array}{c}\text { Stomatal } \\
\text { Conductance }\end{array}$ & $\begin{array}{c}\text { Chlorophyll } \\
\text { Contents }\end{array}$ \\
\hline \multicolumn{4}{c}{ Nitrogen Rates Effect } \\
\hline $\mathrm{N}_{0}\left(0 \mathrm{~kg} \mathrm{~N} \mathrm{ha}^{-1}\right)$ & $12.57 \pm 4.83 \mathrm{~b}$ & $89.08 \pm 64.78 \mathrm{~b}$ & $62.02 \pm 26.08 \mathrm{~b}$ \\
$\mathrm{~N}_{1}\left(197 \mathrm{~kg} \mathrm{~N} \mathrm{ha}^{-1}\right)$ & $22.42 \pm 8.68 \mathrm{a}$ & $119.36 \pm 41.21 \mathrm{a}$ & $81.97 \pm 24.00 \mathrm{a}$ \\
\hline \multicolumn{4}{c}{ Plant $\times$ Plant Spacing effect } \\
\hline $15.0 \mathrm{~cm}$ & $9.54 \pm 3.85 \mathrm{e}$ & $150.05 \pm 30.39 \mathrm{a}$ & $80.24 \pm 26.74 \mathrm{a}$ \\
$22.5 \mathrm{~cm}$ & $12.80 \pm 4.40 \mathrm{~d}$ & $122.39 \pm 26.73 \mathrm{~b}$ & $73.15 \pm 27.51 \mathrm{a}$ \\
$30.0 \mathrm{~cm}$ & $17.01 \pm 5.67 \mathrm{c}$ & $97.06 \pm 39.15 \mathrm{c}$ & $71.63 \pm 24.90 \mathrm{a}$ \\
$37.5 \mathrm{~cm}$ & $21.90 \pm 7.02 \mathrm{~b}$ & $78.44 \pm 29.59 \mathrm{~d}$ & $73.71 \pm 25.05 \mathrm{a}$ \\
$45.0 \mathrm{~cm}$ & $26.23 \pm 8.67 \mathrm{ab}$ & $73.18 \pm 17.96 \mathrm{~d}$ & $78.74 \pm 25.68 \mathrm{a}$ \\
\hline \multicolumn{4}{c}{ Varietal effect } \\
\hline MNH-1016 & $18.20 \pm 9.11 \mathrm{ab}$ & $110.94 \pm 34.95 \mathrm{ab}$ & $66.60 \pm 26.30 \mathrm{~b}$ \\
FH-Lalazar & $16.91 \pm 7.53 \mathrm{bc}$ & $117.08 \pm 30.28 \mathrm{a}$ & $81.21 \pm 24.77 \mathrm{ab}$ \\
NIAB-878 & $19.34 \pm 9.95 \mathrm{a}$ & $100.13 \pm 31.72 \mathrm{bc}$ & $85.15 \pm 23.33 \mathrm{a}$ \\
Cyto-124 & $15.5 \pm 7.36 \mathrm{bc}$ & $88.74 \pm 61.42 \mathrm{c}$ & $69.03 \pm 24.97 \mathrm{a}$ \\
\hline
\end{tabular}

The values are the mean \pm standard deviation $(n=3)$. The values with the same letter $(\mathrm{s})$ within treatment (nitrogen rate, plant spacing, and variety) are statistically nonsignificant. Different letters are showing significant difference at $p \leq 0.05$.

The main and interaction effects of variety, plant spacing, and nitrogen rates were found to be significant on the stomatal conductance at $p<0.05$ (Table 1). The increment in stomatal conductance was $34.0 \%$ with the application of nitrogen fertilizer $197 \mathrm{~kg} \mathrm{ha}^{-1} \mathrm{com}-$ pared to the no nitrogen application. The maximum stomatal conductance was recorded at $22.5 \mathrm{~cm}$ plant spacing while the minimum was at $45.0 \mathrm{~cm}$ (Table 4). The variety FH-Lalazar showed higher stomatal conductance compared to other varieties.

The main effect of variety, plant spacing, and nitrogen rate was found to be significant on chlorophyll contents at $p<0.05$ (Table 1 ). The interaction effect of variety $\times$ plant spacing was also found to be significant. The nitrogen application of $197 \mathrm{~kg} \mathrm{ha}^{-1}$ increased by $32.2 \%$ the chlorophyll contents over no nitrogen application. The $15.0 \mathrm{~cm}$ plant spacing increased chlorophyll contents by $9.7 \%, 12.0 \%, 8.9 \%$ and $1.9 \%$ over $22.5,30.0,37.5$ and $45.0 \mathrm{~cm}$, respectively. The variety NIAB- 878 increased chlorophyll contents by $27.9 \%, 5.0 \%$ and $23.4 \%$ compared to MNH-1016, FH-Lalazar, and Cyto-124, respectively (Table 4).

\subsection{Nitrogen, Phosphorus and Potassium Uptake in Plants}

The main and interaction effects of variety, plant spacings and nitrogen rate were found to be significant on the nitrogen uptake in the plant at $p<0.05$ (Table 1 ). The nitrogen uptake was increased by $31.0 \%$ with nitrogen application $197 \mathrm{~kg} \mathrm{ha}^{-1}$ over no nitrogen application. The plant spacing showed a mixed effect on the nitrogen uptake. The higher nitrogen uptake was seen on 15.0 and $45.0 \mathrm{~cm}$ plant spacings. A slight difference was also observed among varieties on nitrogen uptake (Figure 3). 

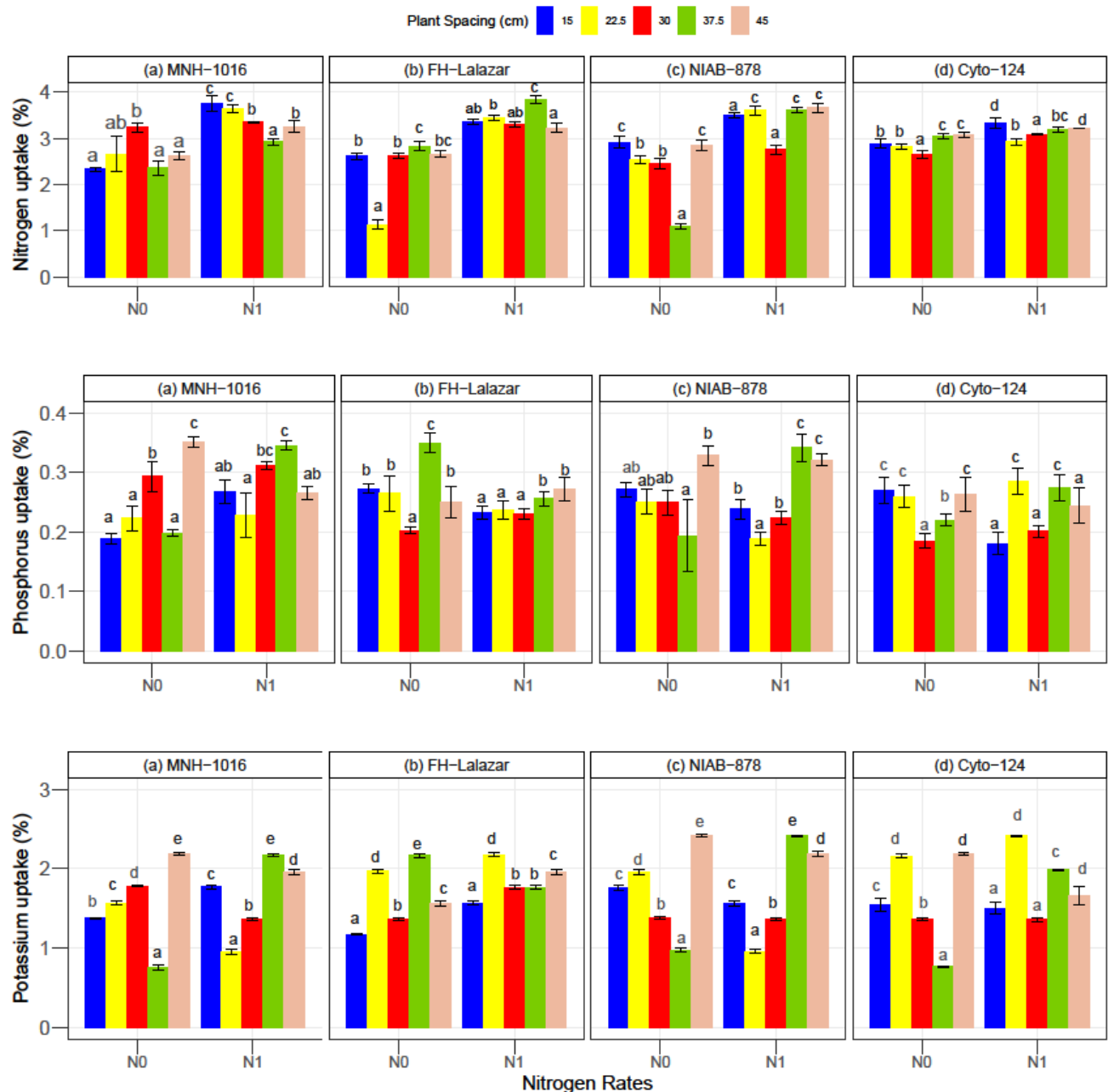

Figure 3. Impact of spacing on the potassium, phosphorus, and nitrogen uptakes of four cotton cultivars under different nitrogen applications; No (no nitrogen application) and N1 (nitrogen application $197 \mathrm{~kg} \mathrm{ha}^{-1}$ ). The same letter (s) within variety and nitrogen rate are statistically nonsignificant. Errors bar represent standard deviation $(\mathrm{n}=3)$. Different letters are showing significant difference at $p \leq 0.05$.

The main effect of variety and plant spacing was found to be significant on phosphorus at $p<0.05$. The interaction effects of variety $\times$ plant spacing, variety $\times$ nitrogen rate, plant spacing $\times$ nitrogen rate, and variety $\times$ plant spacing $\times$ nitrogen rate were also found to be significant on the phosphorus uptake (Table 1). The $45.0 \mathrm{~cm}$ plant spacing showed maximum phosphorus uptake, while 15.0 and $22.5 \mathrm{~cm}$ showed minimum phosphorus uptake. A slight difference was observed in phosphorus uptake in plants among all varieties. The lowest phosphorus uptake was recorded in Cyto-124 (Figure 3).

The main and interaction effects of variety, plant spacing, and nitrogen rate were significant on the potassium uptake at $p<0.05$ (Table 1). The nitrogen application $197 \mathrm{~kg} \mathrm{ha}^{-1}$ showed an increase of $7.4 \%$ over no nitrogen application. The $45.0 \mathrm{~cm}$ plant spacing showed an increase of $31.4 \%, 14.2 \%, 37.7 \%$, and $24.1 \%$ increase in potassium uptake compared to $22.5,30.0,37.5$ and $45.0 \mathrm{~cm}$ plant spacings (Figure 3). The variety FH-Lalazar showed an increase in potassium uptake by $10.1 \%, 3.0 \%$ and $3.0 \%$ compared to MNH-1016, NIAB-878 and Cyto-124, respectively.

\section{Discussion}

The current field study was conducted at the Research Area of MNS, University of Agriculture, Multan, Pakistan, to evaluate the impact of plant spacing on growth, 
yield, physiology, and fiber quality attributes of four cotton cultivars under no nitrogen application and nitrogen application of $197 \mathrm{~kg} \mathrm{ha}^{-1}$. The nitrogen application increased the cotton growth, yield, physiology, and fiber quality attributes compared to no nitrogen application. There was a mixed effect of wider and narrow plant spacing on cotton productivity and fiber quality compared to narrow plant spacing. There was also a mixed effect of varieties on cotton productivity and fiber quality.

The nitrogen application of $197 \mathrm{~kg} \mathrm{ha}^{-1}$ increased the plant height, monopodial branches, leaf area, number of bolls per plant, seed cotton yield, GOT, staple length, micronaire, photosynthetic rate, stomatal conductance chlorophyll contents, and NPK uptake in plants compared to where no nitrogen was applied.

Nitrogen is the main essential and chief nutrient required in large quantities for cotton growth and development. It is the main constituent of protein, chlorophyll, and is a part of the cell organelles. The increase in plant height of many crops by applying nitrogen is reported in the literature [22,23]. Our results were in line with Kumbhar et al. [23], who reported that nitrogen plays a part in the accelerated vegetative growth of the plants. The deficiency of nitrogen affects crop growth and yield of seed cotton. Maximization of $\mathrm{N}$ fertilizer is the purpose for better management [24]. In several crops, for instance, cotton, a surplus quantity of $\mathrm{N}$ may enhance vegetative growth and delay maturity, resulting in low yield [25]. The present study results show that nitrogen application has a significant effect on number of bolls per plant. This could be due to nitrogen fertilization, as the cotton plant is highly responsive to nitrogen uptake. These consequences are similar to Rabia et al. [26]. They stated that an increase in nitrogen also significantly increases the number of bolls per plant due to cotton being more responsive to nitrogen than other crop plants. Nitrogen fertilization has a significant effect on fiber fineness. This may be due to unique genotypic effects or suitable environmental conditions. Moreover, fiber quality is affected by nitrogen fertilization $[27,28]$.

Nitrogen application has a significant effect on chlorophyll content. This was due to the fact that the cotton plant is highly responsive towards nitrogen. The highest chlorophyll content could be due to better assimilation and translocation of photosynthates [29]. The chlorophyll content (SPAD values) increased where nitrogen was applied. The highest SPAD values were observed at 90 days after planting. The increase in chlorophyll content resulted from increased leaf $\mathrm{N}$ uptake in leaf tissue and sufficient availability of nitrogen fertilizer [30]. The results agree with those of Boquet et al. [31], who reported a strong association between nitrogen rate and SPAD values.

The wider plant spacings increased monopodial branches. However, sympodial branches and boll weight was increased where no nitrogen fertilizers were applied. The wider plant spacing $(45.0 \mathrm{~cm})$ increased monopodial branches, boll weight, boll numbers, GOT, staple length, micronaire, photosynthetic rate, stomatal conductance, and phosphorus uptake in plants. However, the narrow plant spacing results were also the best for monopodial branches, sympodial branches, leaf area, seed cotton yield, stomatal conductance, chlorophyll contents and nitrogen uptake. These findings are related to those of Anjum [32], who reported that different plant spacings did not significantly influence the plant height of cotton due to different genetic makeup. On the contrary, Rabia et al. [33] and Qamar et al. [34] reported that plant spacing on plant height was found to be significant, as plants luxuriously utilized all resources and light interception was also better. Plant density affects light interception, moisture availability, nutrient uptake, humidity, and weed infestation, [35] and thus influences plant height, fruiting behavior, maturity and final yield. More competition among plants suppresses plant growth under high density. Higher plant density resulted in a lesser internodal distance [36]. This is in affirmation with the earlier findings of Stephenson et al. [37], who concluded that higher plant density decreased the number of monopodial and sympodial branches. With the increase in plant spacing, the number of sympodial branches per plant also increased. Alfaqeih [38] also reported similar results. An increase in the number of sympodial branches per plant in low planting density could be due to less competition and more space available for the 
growth of plants. The number of plants per area was greater in narrow spacing treatments. The plants in the narrow spacing $(15 \mathrm{~cm})$ were dense $\left(86,109\right.$ plants ha $\left.^{-1}\right)$, while at wider spacing $(45.0 \mathrm{~cm})$ the number of plants was lower, i.e., 28,703 plants $\mathrm{ha}^{-1}$. These findings are related to those described by Chhabra and Bishoni 1993. They revealed that boll weight and number of bolls decrease with narrow spacing, but yield per hectare increased. Due to the maximum plant population and nitrogen fertilization, the cotton yield was directly increased. Parlawar et al. [39] also reported that maximum seed cotton yield in narrow spacing is due to the high plant population. Ali et al. [40] stated that the highest seed cotton yield was gained with spacing $15 \mathrm{~cm}$. Similar findings were reported by Delaney et al. [41]; Brodrick et al. [42] and Singh et al. [43]. By increasing space, it was observed that boll weight increased, which led to the highest seed cotton yield. Boll weight showed a decreasing trend with the decrease in plant spacing as well as without nitrogen. Heavier bolls in wider spacing may be because of less competition amongst crop plants, resulting in efficient consumption of all resources. These findings are found to be similar to Alfaqeih et al. [38], Clawson et al. [44] and Shah et al. [45]. They reported that wider spacing increased the number of branches per plant and boll weight which was due to less competition between plants. The results were similar to those reported by Hussain et al. [46] and Alfaqeih et al. [38]. They reported that an increase in the number of bolls per plant was a direct consequence of more sympodial branches per plant. In addition, Iqbal et al. [29] revealed that an increase in the number of bolls per plant with an increase in plant spacing can reduce competition between plants. Space availability would have enabled the plants to uptake more water and nutrients to produce a greater number of sympodial branches. This finally would have resulted in a greater number of bolls per plant. In addition, the highest number of bolls could be due to better assimilation and translocation of photosynthates [28]. These findings were similar to Shukla et al. [47] and Sisodia et al. [48]. They stated that leaf area index increases with a decrease in plant spacing or narrow spacing. Higher LAI could be due to less availability of horizontal space available for an individual plant. So this is why the plant grows taller with respect to vertical space, and produces a greater number of leaves, sympodial branches per plant and is accompanied by a greater number of plants per unit area, which leads to a higher yield under closer spacing. Contrasting results were found by Arunvenkatesh et al. [49]. They stated that different plant spacing did not affect the micronaire values. In addition, many reports have presented the significance of appropriate planting density and spacing, that differ across various environments and cotton varieties, to obtain maximum seed cotton yield along with improved fiber quality $[50,51]$. In previous studies there were nonsignificant differences among various plant spacings, so there was no effect on ginning out turn. These results are similar to Hussain et al. [45], who stated that plant spacing did not affect ginning out turn. Varieties also showed nonsignificant results. Therefore, it is concluded that GOT is genetically controlled. Donald [52] also concluded the same results. In addition, at wider spacing, plants have more availability to meet their requirements, and less competition is found among plants.

The variety MNH-1016 showed higher values for leaf area, boll numbers, boll weight, seed cotton yield, and micronaire, compared to other varieties. The variety FH-Lalazar showed an increase in GOT, stomatal conductance and potassium uptake over other varieties. The NIAB- 878 showed higher staple length, photosynthetic rate, stomatal conductance, and phosphorus uptake in plants compared to other varieties. The cyto-124 showed an increase in plant height, monopodial branches, leaf area and nitrogen uptake. A positive correlation between boll weight and all other parameters was seen.

The findings agreed with $[53,54]$. N-efficient cultivars have strong adaptability and tend to grow in reproductive organs and are beneficial to the formation of boll number and boll weight, especially under low $\mathrm{N}$ conditions. As far as the effect of plant height on different genotype is concerned, it was statistically significant due to different varietal characters [55]. The difference in micronaire values was due to different varieties. This 
could be due to the difference in genetic vigor. Similar differences in micronaire values due to different cultivars have also been reported by Faircloth et al. [54].

So far, numerous studies have found that various crops with different genotypes display variance in nitrogen absorption and nitrogen utilization. The yield differences between cultivars may be mainly caused by nitrogen absorption capacity and nitrogen transferred to reproductive organs. Therefore, we should choose or breed varieties with strong absorption and transferability to reduce the $\mathrm{N}$ fertilization application under the premise of ensuring yield. In addition, at wider spacing, plants have more availability to meet their requirements, and less competition was found among plants.

\section{Conclusions}

The nitrogen application of $197 \mathrm{~kg} \mathrm{ha}^{-1}$ increased the cotton growth, yield, physiology, and fiber quality attributes compared with no nitrogen application. There was a mixed effect of wider and narrow plant spacings on cotton productivity and fiber quality. However, wider plant spacing affected cotton growth, physiology, yield, and fiber quality attributes. There was also a mixed effect of variety on cotton productivity and fiber quality. However, the performance of MNH-1016 and NIAB-878 was found to be higher than FH-Lalazar and Cyto-124. Long-term studies under different ecological conditions are suggested to further explore the role of different plant spacings on the cotton productivity of different cultivars under sufficient amounts of nitrogen fertilizers.

Author Contributions: Conceptualization, I.Z., M.A. and K.S.; methodology, M.A., M.S.T., A.M. and W.A.; software, K.S.; validation, M.A. and I.Z.; formal analysis, I.Z., M.R.K. and M.M.Q.; investigation, I.Z., M.A. and A.W.; writing-original draft preparation, K.S.B., M.R.K., S.A., M.H.S., S.F. and R.D.; writing-review and editing, K.S.B., M.R.K., S.A., M.H.S., S.F. and R.D.; supervision, M.A.; funding acquisition, M.A., S.A., M.H.S. and S.F. All authors have read and agreed to the published version of the manuscript.

Funding: Researchers Supporting Project number (RSP-2021/194), King Saud University.

Institutional Review Board Statement: Not applicable.

Informed Consent Statement: Not applicable.

Data Availability Statement: Not applicable.

Acknowledgments: Authors would like to extend their sincere appreciation to the Researchers Supporting Project number (RSP-2021/194), King Saud University, Riyadh, Saudi Arabia.

Conflicts of Interest: The authors declare no conflict of interest.

\section{References}

1. Anonymous. Economics Survey of Pakistan, 2016-17; Ministry of Food, Agriculture and Livestock, Finance Advisors Wing: Islamabad, Pakistan, 2017; p. 3.

2. Anonymous. Economics Survey of Pakistan, 2019-20; Ministry of Food, Agriculture and Livestock, Finance Advisors Wing: Islamabad, Pakistan, 2020; p. 20.

3. Owen Gwathmey, C.; Chism Craig, C., Jr. Managing earliness in cotton with mepiquat type growth regulators. Crop Manag. 2003, 2, 1-8. [CrossRef]

4. Zhao, W.; Wang, Y.; Zhou, Z.; Meng, Y.; Chen, B.; Oosterhuis, D.M. Effect of nitrogen rates and flowering dates on fiber quality of cotton (Gossypium hirsutum L.). J. Exp. Agric. Int. 2012, 2, 133-159. [CrossRef]

5. Ali, A.; Tahir, M.; Ayub, M.; Ali, I.; Wasaya, A.; Khalid, F. Studies on the effect of plant spacing on the yield of recently approved varieties of cotton. Pak. J. Life Soc. Sci. 2009, 7, 25-30.

6. Arshad, M.; Wajid, A.; Maqsood, M.; Hussain, K.; Aslam, M.; Ibrahim, M. Response of growth, yield and quality of different cotton cultivars to sowing dates. Pak. J. Agric. Sci. 2007, 44, 208-212.

7. Edward, J.; Martin, D.P. Effect of sowing time on yield and quality of canola. Int. J. Crop Prod. 2009, 6, 3-5.

8. Nichols, S.P.; Snipes, C.E.; Jones, M.A. Cotton growth, lint yield, and fiber quality as affected by row spacing and cultivar. J. Cotton Sci. 2004, 8, 1-12.

9. Crews, T.E.; Peoples, M.B. Can the synchrony of nitrogen supply and crop demand be improved in legume and fertilizer-based agroecosystems? A review. Nutr. Cycl. Agroecosyst. 2005, 72, 101-120. [CrossRef] 
10. Howard, D.D.; Gwathmey, C.O.; Essington, M.E.; Roberts, R.K.; Mullen, M.D. Nitrogen fertilization of no till cotton on loess derived soils. Agron. J. 2001, 93, 157-163. [CrossRef]

11. Borowski, E. The effect of nitrogenous compounds on the growth, photosynthesis and phosphorus uptake of sunflowers. In Proc. Ann. Univ. Mariae Curie-Sklodowska Sect. EEE Hortic. 2001, 9, 23-31.

12. Perumai, N.K. Effect of different nitrogen levels on morpho-physiological characters and yield in rainfed cotton. Indian J. Plant Physiol. 1999, 4, 65-67.

13. Gangaiah, B.; Ahlawat, I.P.S.; Babu, M. Response of nitrogen fertilization on Bt and non-Bt cotton (Gossypium hirsutum) hybrids. SAARC J. Agric. 2013, 11, 121-132. [CrossRef]

14. Ali, H.; Afzal, M.N.; Ahmad, F.; Ahmad, S.; Akhtar, M.; Atif, R. Effect of sowing dates, plant spacing and nitrogen application on growth and productivity on cotton crop. Int. J. Sci. Eng. Res. 2011, 2, 1-6.

15. Marfo, T.D.; Datta, R.; Pathan, S.I.; Vranová, V. Ecotone Dynamics and Stability from Soil Scientific Point of View. Diversity 2019, 11, 53. [CrossRef]

16. Danso Marfo, T.; Datta, R.; Vranová, V.; Ekielski, A. Ecotone Dynamics and Stability from Soil Perspective: Forest-Agriculture Land Transition. Agriculture 2019, 9, 228. [CrossRef]

17. Saleem, M.F.; Bilal, M.F.; Awais, M.; Shahid, M.; Anjum, S.A. Effect of nitrogen on seed cotton yield and fiber qualities of cotton (Gossypium hirsutum L.) cultivars. J. Anim. Plant Sci. 2010, 20, $23-27$.

18. Watson, D.J. Comparative physiological studies on the growth of field crops: I. Variation in net assimilation rate and leaf area between species and varieties, and within and between years. Ann. Bot. 1947, 11, 41-76. [CrossRef]

19. Bremner, J.M.; Mulvaney, C.S. Nitrogen-total. In Methods of Soil Analysis. Part 2. Chemical and Microbiological Properties; Page, A.L., Miller, R.H., Keeney, D.R., Eds.; American Society of Agronomy, Soil Science Society of America: Madison, WI, USA, 1982; pp. 595-624.

20. Jackson, M.L. Soil Chemical Analysis; Prentice Hall, Inc.: Englwood Cliff, NY, USA, 1962.

21. Alam, M.M.; Alam, A.K.M.; Khandker, S.; Gani, M.N.; Ahmed, S.A.; Haque, A. Fertilizer management of late jute seed production in different agro-ecological zones of Bangladesh. Pak. J. Biol. Sci 2002, 5, 410-412. [CrossRef]

22. Kumbhar, A.M.; Buriro, U.A.; Junejo, S.; Oad, F.C.; Jamro, G.H.; Kumbhar, B.A.; Kumbhar, S.A. Impact of different nitrogen levels on cotton growth, yield and N-uptake planted in legume rotation. Pak. J. Bot 2008, 40,767-778.

23. Dong, Y.; Pollock, N.; Stallmann-Jorgensen, I.S.; Gutin, B.; Lan, L.; Chen, T.C.; Keeton, D.; Petty, K.; Holick, M.F.; Zhu, H. Low 25Hydroxyvitamin D Levels in Adolescents: Race, Season, Adiposity, Physical Activity, and Fitness. Pediatrics 2010, 125, $1104-1111$. [CrossRef]

24. Rinehardt, J.M.; Edmisten, K.L.; Wells, R.; Faircloth, J.C. Response of ultra-narrow and conventional spaced cotton to variable nitrogen rates. J. Plant Nutr. 2004, 27, 743-755. [CrossRef]

25. Mushtaq, R.; Pundir, J.; Achilli, C.; Naji, O.; Khalaf, Y.; El-Toukhy, T. Effect of male body mass index on assisted reproduction treatment outcome: An updated systematic review and meta-analysis. Reprod. Biomed. 2018, 36, 459-471. [CrossRef] [PubMed]

26. Rashidi, M.; Gholami, M. Response of yield and yield components of cotton to different rates of nitrogen fertilizer. Acad. J. Plant Sci. 2011, 4, 22-25.

27. Seilsepour, M.; Rashidi, M.; Yarmohammadi-Samani, P. Response of biological growth and fiber quality of cotton to different application rates of nitrogen. Middle East J. Sci. Res. 2013, 14, 838-842.

28. Iqbal, M.; Ahmad, S.; Nazeer, W.; Muhammad, T.; Khan, M.B.; Hussain, M.; Mehmood, A.; Tauseef, M.; Hameed, A.; Karim, A. High plant density by narrow plant spacing ensures cotton productivity in elite cotton (Gossypium hirsutum L.) genotypes under severe cotton leaf curl virus (CLCV) infestation. African J. Biotechnol. 2012, 11, 2869-2878.

29. Khan, M.B.; Hussain, N.; Asif, M. Growth and yield of cotton as influenced by various nitrogen levels and plant population. Int. J. Agric. Biol 2001, 3, 5-7.

30. Boquet, D.J.; Holman, E.M.; Brown, R.E.A.; Thomas, W.J.; Coco, A.B. Use of a chlorophyll meter to determine cover crop, rotation and N rate effect on crop N status. Proceedings 1999, 2, 1269-1271.

31. Anjum, F.; Yaseen, M.; Rasool, E.; Wahid, A.; Anjum, S. Water stress in barley (Hordeum vulgare L.) on chemical composition and chlorophyl contents. Pak. J. Agric. Sci. 2003, 40, 45-49.

32. Panhwar, R.B.; Akbar, A.; Panhwar, B.U.; Panhwar, G.A.; Bai-li, F. Effects of plant spacing and nitrogen fertilizer levels on cotton yield and growth. Int. J. Sci. Environ. Technol. 2018, 7, 313-324.

33. Rafi, Q.; Allah, D.; Abdul, R.; Safdar, M.E.; Muhammad, S.; Javeed, H.M.R.; Amjed, A. Response of Bt. cotton to different nitrogen doses and plant spacing. Acad. J. Agric. Res. 2015, 3, 342-347.

34. Siebert, J.D.; Stewart, A.M. Influence of plant density on cotton response to mepiquat chloride application. Agron. J. 2006, 98, 1634-1639. [CrossRef]

35. Stephenson IV, D.O.; Barber, L.T.; Bourland, F.M. Effect of twin-row planting pattern and plant density on cotton growth, yield, and fiber quality. J. Cotton Sci. 2011, 15, 243-250.

36. Alfaqeih, F.M.; Ali, A.M.; Baswaid, A.S. Effect of plant density on growth and yield of cotton. J. Nat. Appl. Sci 2002, 6, $279-285$.

37. Parlawar, N.D.; Jiotode, D.J.; Kubde, K.J.; Khawle, V.S.; Puri, P.D. Effect of plant geometry under hdps on crop phenology and yield contributing characters in cotton. J. Soils Crop. 2017, 27, 274-280.

38. Ali, M.; Ali, L.; Sattar, M.; Ali, M.A. Response of seed cotton yield to various plant populations and planting methods. J. Agric. Res. 2010, 48, 164-169. 
39. Delaney, D.P.; Reeves, D.W.; Monks, C.D.; Patterson, M.G.; Mullins, G.L.; Gamble, B.E. Cover crops and tillage combinations for wide and ultra narrow row cotton. In Proceedings of the 25th Annual Southern Conservation Tillage Conference for Sustainable Agriculture, Auburn, AL, USA, 24-26 June 2002.

40. Brodrick, R.; Bange, M.P.; Milroy, S.P.; Hammer, G.L. Physiological determinants of high yielding ultra-narrow row cotton: Biomass accumulation and partitioning. Field Crop. Res. 2012, 134, 122-129. [CrossRef]

41. Singh, J.; Babar, S.; Abraham, S.; Venugopalan, M.V.; Majumdar, G. Fertilization of high density, rainfed cotton grown on vertisols of India. Better Crop. 2012, 96, 26-28.

42. Ernest, L.; Clawson, J.; Cothren, T.; Blouin, D.C. Nitrogen fertilization and yield of cotton in ultra-narrow and conventional row spacing. Agron. J. 2006, 98, 72-79.

43. Shah, T.; Kalsoom, M.; Eifediye, K.; Khan, H.A. Yield and quality characters of cotton varieties response to different plant spacing. Middle East J. Agric. Res 2017, 6, 113-118.

44. Hussain, S.Z.; Sheraz, F.; Anwar, M.; Gill, M.I.; Baugh, M.D. Effect of plant density and nitrogen on the yield of seed cotton-variety CIM-443. Sarhad J. Agric. 2000, 16, 143-147.

45. Shukla, U.N.; Khakare, M.S.; Bhale, V.M.; Singh, S. Plant population, nutrient uptake and yield of cotton (Gossypium hirsutum) hybrids as affected by spacing and fertility levels under rainfed condition. Indian J. Agric. Res. 2013, 47, 83-88.

46. Sisodia, R.I.; Khamparia, S.K. American cotton varieties as influenced by plant densities and fertility levels under rainfed conditions. J. Cott. Res. Dev. 2007, 21, 35-40.

47. Arunvenkatesh, S.; Rajendran, K. Evaluation of plant density and cotton genotypes (Gossypium hirsutum L.) on cotton yield and fibre quality. Int. J. For. Crop Improv. 2013, 4, 1-5.

48. Iqbal, M.; Khan, M.A. Management of cotton leaf curl virus by planting time and plant spacing. Adv. Agric. Bot. 2010, 2, 25-33.

49. Nadeem, M.A.; Ali, A.; Tahir, M.; Naeem, M.; Chadhar, A.R.; Ahmad, S. Effect of nitrogen levels and plant spacing on growth and yield of cotton. Pak. J. Life Soc. Sci. 2010, 8, 121-124.

50. Boquet, D.J. Cotton in ultra narrow row spacing: Plant density and nitrogen fertilizer rates. Agron. J. 2005, 97, 279-287. [CrossRef]

51. Dai, J.; Li, W.; Tang, W.; Zhang, D.; Li, Z.; Lu, H.; Eneji, A.E.; Dong, H. Manipulation of dry matter accumulation and partitioning with plant density in relation to yield stability of cotton under intensive management. Field Crop. Res. 2015, 180, 207-215. [CrossRef]

52. Luo, J.; Zhou, J.; Li, H.; Shi, W.; Polle, A.; Lu, M.; Sun, X.; Luo, Z.-B. Global poplar root and leaf transcriptomes reveal links between growth and stress responses under nitrogen starvation and excess. Tree Physiol. 2015, 35, 1283-1302. [CrossRef] [PubMed]

53. Wankhade, S.T.; Turkhade, A.B.; Katkar, R.N.; Sakhare, B.A.; Solanke, V. Effect of plant population on growth and yield of G. hirsutum cotton variety PKV Rajat under drip. PKY Res. J. 2002, 26, 124-126.

54. Faircloth, J.C.; Edmisten, K.L.; Wells, R.; Stewart, A.M. The influence of defoliation timing on yields and quality of two cotton cultivars. Crop Sci. 2004, 44, 165-172. [CrossRef]

55. Moll, R.H.; Kamprath, E.J.; Jackson, W.A. Analysis and interpretation of factors which contribute to efficiency of nitrogen utilization 1. Agron. J. 1982, 74, 562-564. [CrossRef] 